\title{
North American Co-operative Bird Migrating Study - 1957
}

We hope most of our members will ke part in this year's bird migraon study-in co-operation with bird atchers across the continent. In ddition to the first seen dates, lake note of any heavy migration aves for the species involved. When ossible, give number of individuals een on the first seen date and numer of individuals seen with the eak migration wave for that spees. The species chosen are fairly pmmon and easy to identify, so that veryone can take part. These recrds will be summarized for the lue Jay and then forwarded to udubon Field Notes and the U.S. ish and Wildlife Service. Don't dey. Send spring migration dates to r. Stuart Houstion, Box 278, Yorkon, Sask., for the following species: Thistling Swan, Canada Goose. Malrd, Pintail, Marsh Hawk, Killdeer,
Wilson's Snipe, Mourning Dove, Nighthawk, Ruby-throated Hummingbird, Flicker, Eastern Kingbird, Eastern Phoebe, Barn Swallow, Purple Martin, Crow, Catbird, House Wren, Brown Thrasher, Red-eyed Vireo, Black and White Warbler, Yellow Warbler, Myrtle Warbler, Ovenbird, Redstart, Red - winged Blackbird, Baltimore Oriole, Rosebreasted Grosbeak, Goldfinch, Slatecolored Junco, Chipping Sparrow, White-crowned Sparrow, and Whitethroated Sparrow.

We would like dates also, for any of the following species, less commonly seen in Saskatchewan but being included in the co-operative migration study in the east: Chimney Swift, Crested Flycatcher, Eastern Bluebird, Scarlet Tanager, Indigo Bunting.

\section{Museum Expedition Underground}

\section{By RICHARD W. FYFE, Saskatchewan Museum of Natural History}

A museum expedition to Estevan $n$ March 15th of this year has reealed some fascinating underround natural history in the coal ines in the Long Creek area. Orsinally, the expedition was underaken to make a brief archaeological econnaissance of the area and to xamine the mines for hibernating ats.

We found on arrival that many of he mines had been closed down for everal years and that most of these ad since caved in, making an ex. ensive search impossible. However, ye were informed that one mine had een in operation as late as the preious fall, and we decided to explore first. The mine entrance was herely a large hole about 7 feet igh and 12 feet wide in the hillside ading to a horizontal shaft hunreds of feet long.

Just within the entrance we beeld some of the most beautiful crytal formations we had ever viewed.
The roof and the walls of the mine entrance were lined for about 100 feet with spectacular ice crystals, some of which were up to 18 or 20 inches in length. Deeper in the shafts the crystals were much shorter and they disappeared eventually as air warmed the interior.

The second discovery was what appeared to be amber-colored crystalline stalagmites on the mine floor. These stalagmites of ice were identical in shape with their stone counterparts in some of the southern caverns. Generally these stalagmites were banded with color and apparently shaped by alternate periods of freezing and thawing during the winter.

We examined all the shafts in the mine but on a cursory examination did not find any bats. However, on a return visit and with the aid of the mine owner we were able to locate our first recorded cave hibernating bats in drill holes. Big Brown and Little Brown Bats were found. 


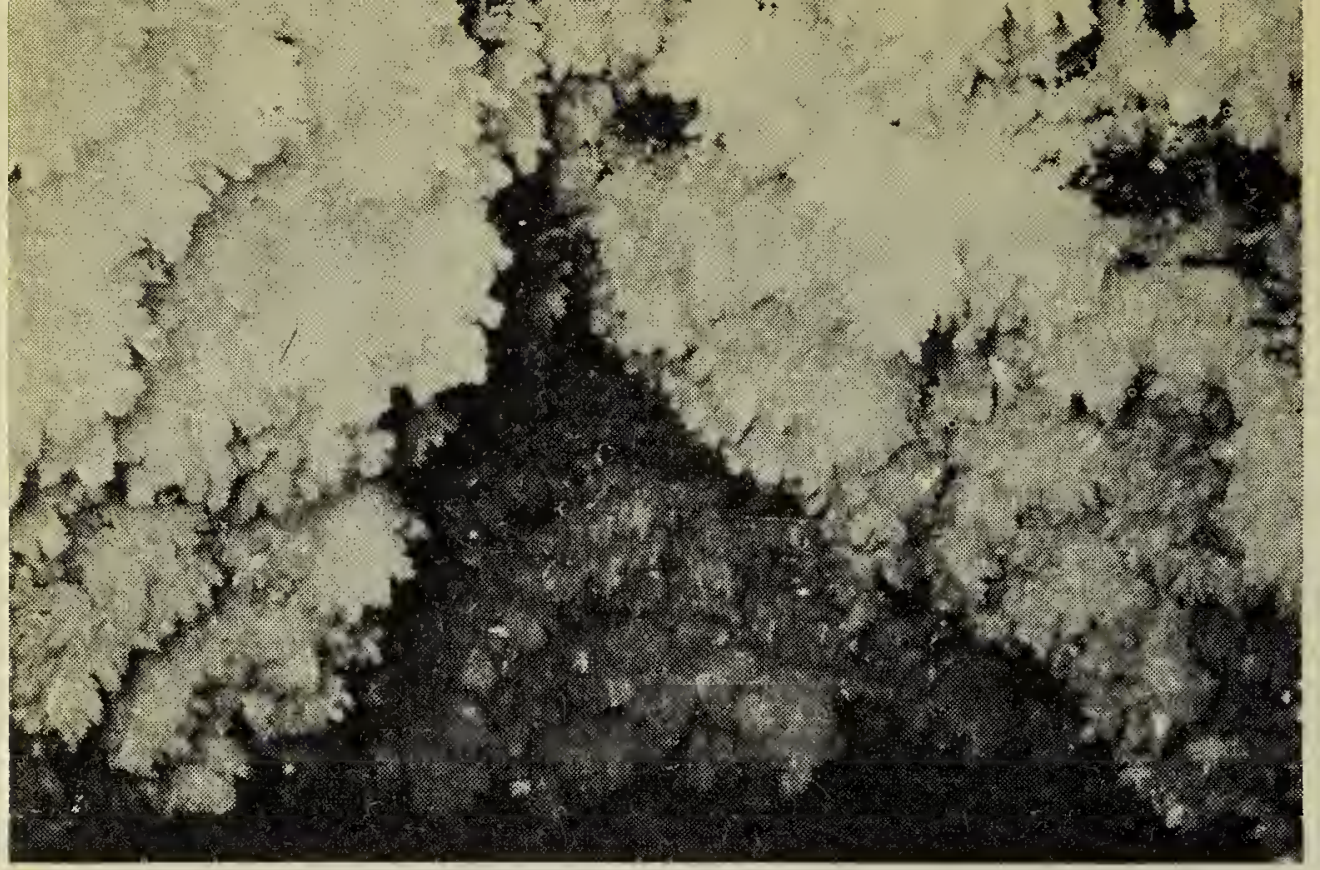

EXPEDIT]

Mine entrance lir about 100 feet $w$ crystals

1 mammoth ice crystal, n. actual size about 18 nches from top to bottom
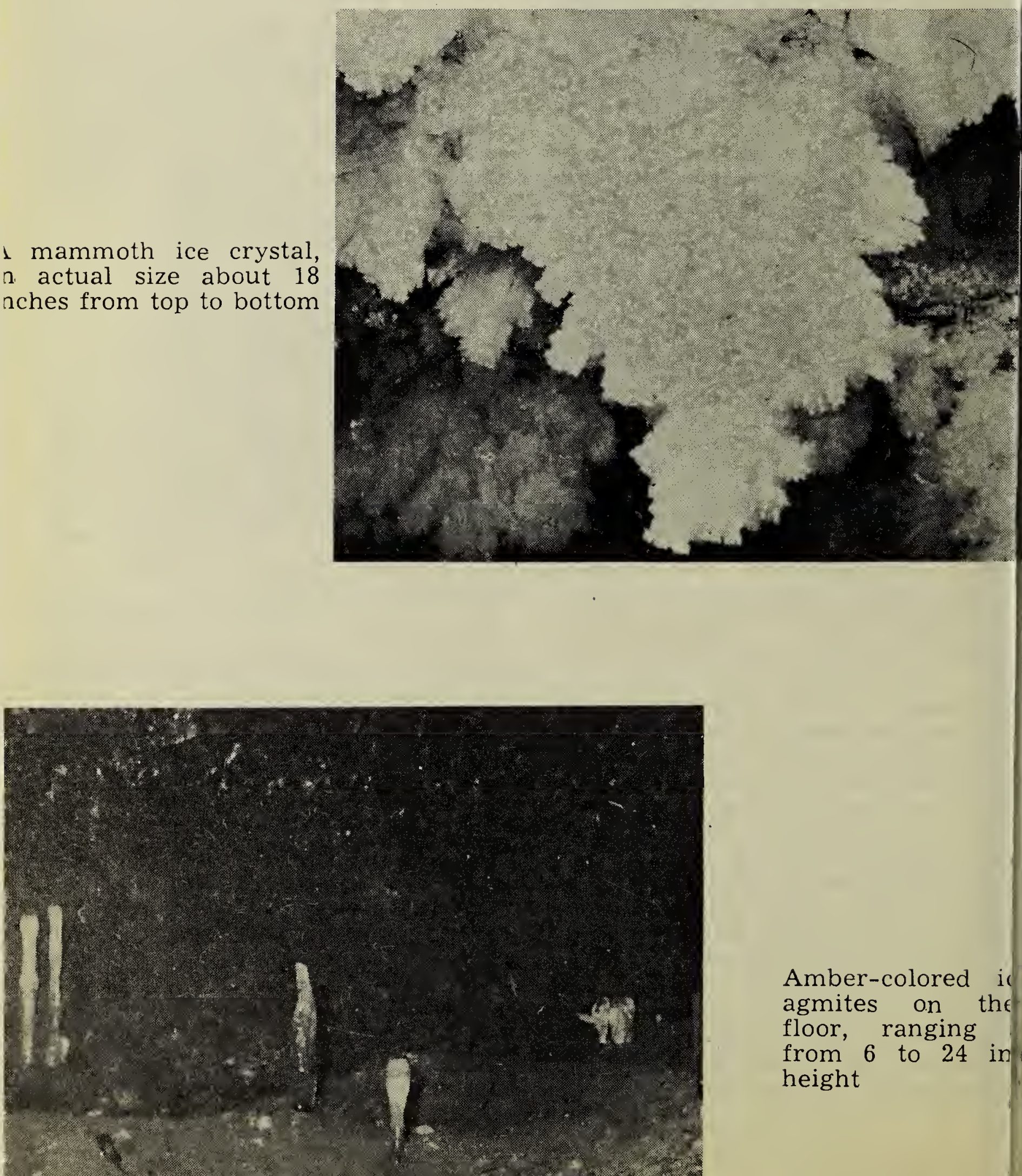

Amber-colored is agmites on the floor, ranging from 6 to 24 in height 


\section{RGROUND}

Iry Big Brown Bat hed from its winter
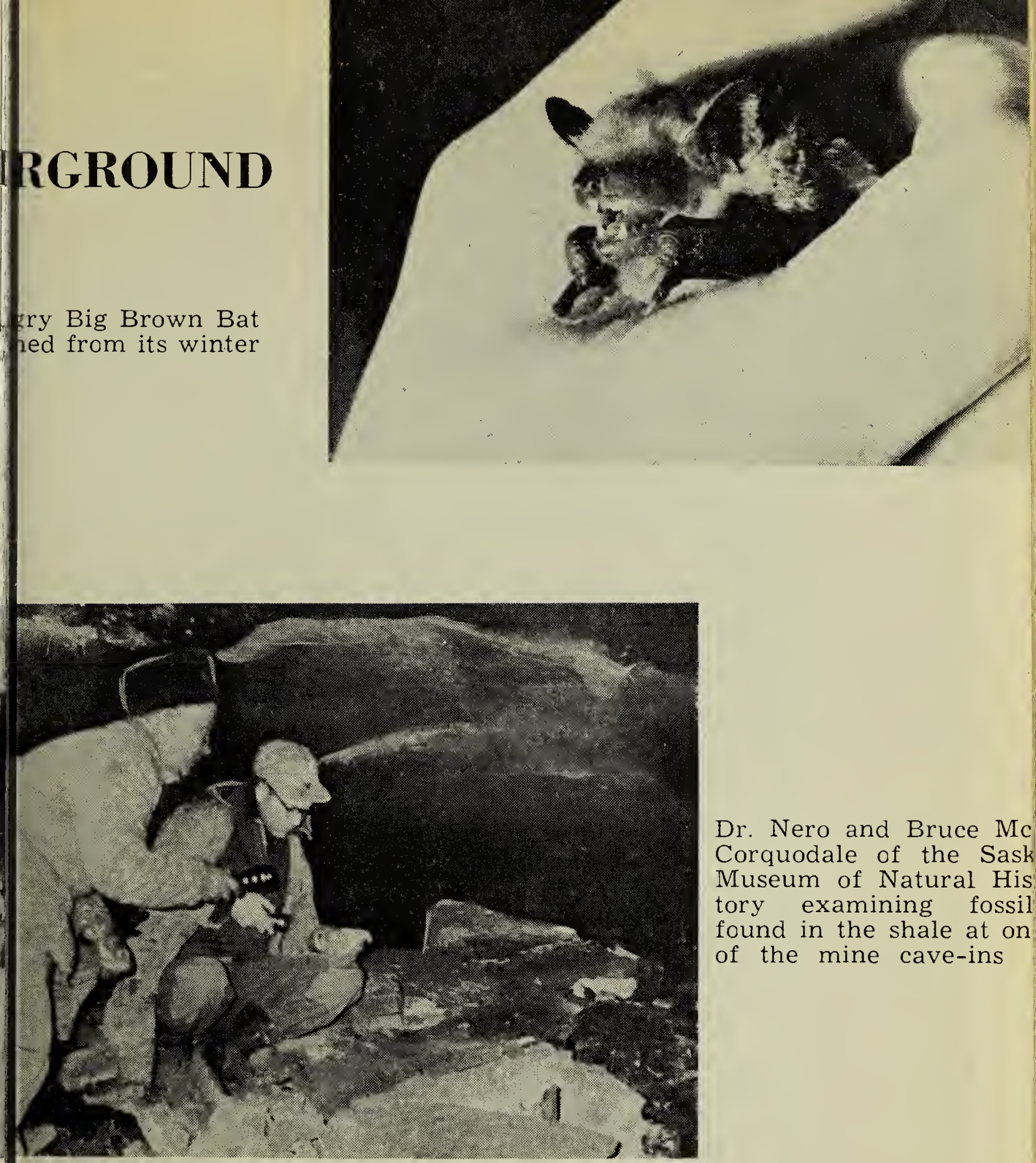

Dr. Nero and Bruce Mc Corquodale of the Sask Museum of Natural His tory examining fossil found in the shale at on of the mine cave-ins

ip of clam and hells embedded in ale. Estimated to 00 years old

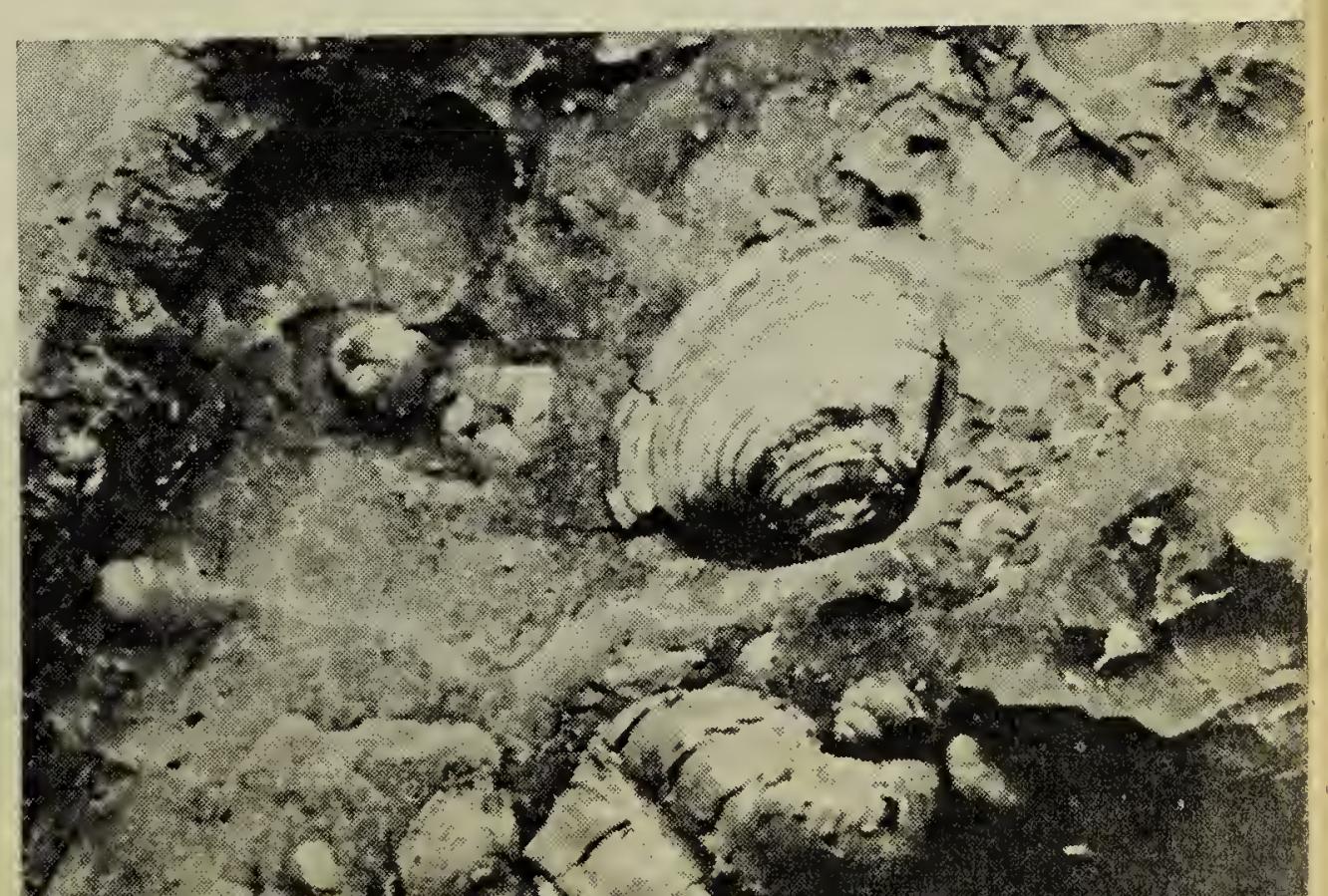

